\title{
VIDEO ENDOSCOPIC INGUINAL LYMPHADENECTOMY (VEIL): INITIAL CASE REPORT AND COMPARISON WITH OPEN RADICAL PROCEDURE.
}

\author{
Marcos Tobias-Machado*, Alessandro Tavares, Wilson R. Molina Jr., João Paulo Zambon, \\ Jimmy Angel Medina, Pedro H. Forseto Jr, Roberto V. Juliano and Eric R. Wroclawski.
}

Section of Oncology and Laparoscopy. Institute of Urology. ABC Medical School. Santo Andre, SP. Brazil

\begin{abstract}
Summary.- OBJECTIVES: Inguinal metastases are one of the major determinants of mortality in patients with penile cancer. In high risk patients, while prophylatic inguinal lymphadenectomy may offer survival advantages, it still carries a relatively high morbidity. We describe in this paper the first report of the Video Endoscopic Inguinal Lymphadenectomy (VEIL) in the clinical practice, a technique which aims at reducing the morbidity of the procedure without compromising the cancer control or reducing the template of the dissection.
\end{abstract}

METHODS: A 40-year old male with a pT2 penile cancer underwent prophylatic bilateral inguinal lymphadenectomy 6 weeks after partial penectomy. We performed the VEIL technique at the right and a standard radical inguinal lymphadenectomy through an inguinal incision at the left (control). After developing a plane deep to Scarpa's fascia, locating 3 ports and infusing gas at $5.10 \mathrm{mmHg}$, a retrograde dissection with the same limits as the standard open surgery was performed. Intraoperative data, patology, post operatory evolution and oncological follow-up is described for both sides.

RESULTS: Operative time was $130 \mathrm{~min}$ for the VEIL and 90 min for open surgery. Eight and 7 lymphnodes were retrieved at the VEIL side and open side, respectively, and none of then showed positivity at pathology. There were no complications in the limb which underwent the VEIL and there was skin necrosis in the side of the open surgery. After 25 months of follow up, no signs of disease progression were noted. Asked about how he felt about both surgeries, the patient chose the endoscopic approach.

CONCLUSION: VEIL is feasible in clinical practice. New studies with a greater number of patients and long-term follow-up may confirm the oncological efficacy and possible lower morbidity of these new approach.

Keywords: Laparoscopy. Inguinal lymphadenectomy. Penile cancer. Urethral cancer. Vulvar cancer.

Resumen.- OBJETIVOS: Las metástasis inguinales son uno de los factores pronósticos más importantes de mortalidad en pacientes con cáncer de pene. La linfadenectomía inguinal profiláctica puede mejorar la supervivencia en pacientes de alto riesgo, pero conlleva una morbilidad relativamente alta. En este artículo comunicamos por primera vez la linfadenectomía inguinal videoendoscópica en la práctica clínica; la técnica busca reducir la morbilidad del procedimiento sin comprometer el control oncológico ni reducir el área de resección. 
MÉTODOS: Paciente de 40 años de edad con cáncer de pene estadio pT2 que se somete a linfadenectomía inguinal bilateral profiláctica seis semanas después de una penectomía parcial. Realizamos la técnica de VEIL en el lado derecho y linfadenectomía inguinal radical abierta estándar en el lado izquierdo (control). Después de desarrollar un plano en profundidad hasta la fascia de Escarpa, insertar tres trocares e infundir gas a 5-10 $\mathrm{mm} \mathrm{Hg}$, se realiza una disección retrógrada con los mismos límites que en el procedimiento abierto estándar. Se describen los datos intraoperatorios, anatomopatológicos, postoperatorios y de seguimiento oncológico en ambos lados.

RESULTADOS: El tiempo operatorio fue de 130 minutos para la VEll y 90 minutos para la cirugía abierta. Se obtuvieron ocho y siete ganglios respectivamente, siendo todos negativos en el estudio anatomopatológico. No hubo complicaciones en el lado de la VEIL, en el lado abierto se produjo necrosis cutánea. Después de 25 meses de seguimiento no hay signos de progresión de la enfermedad. Preguntado el paciente sobre cómo se sentía con ambas cirugías eligió el abordaje endoscópico.

CONCLUSIONES: La linfadenectomía inguinal videoendoscópica es factible en la práctica clínica. Nuevos estudios con mayor número de pacientes y seguimiento a largo plazo pueden confirmar la eficacia y posible menor morbilidad de este nuevo abordaje.

Palabras clave: Laparoscopia. Linfadenectomía inguinal. Cáncer de pene. Cáncer de uretra. Cáncer de vulva.

\section{INTRODUCTION}

Inguinal metastases are one of the major determinants of mortality in patients with penile cancer. In high risk patients, prophylatic inguinal lymphadenectomy may offer survival advantages over watchful waiting. Following treatment of primary tumor, radical inguinal lymphadenectomy (IL) is the standard of care for patients with stage $T \geq 2$, high histologic grade (2 or 3 ) or inguinal nodes after 6 weeks of antibiotic therapy for squamous cell carcinoma of the penis $[1,2]$. Although well established, contemporary series shows that IL remains a procedure with at least $50 \%$ incidence of major complications such as lymphocele, skin loss and infection [3].

Some authors have described alternative procedures to reduce the morbidity of the treatment of inguinal lymph nodes, mainly by decreasing the area of dissection $[4,5]$ but oncological results may not be as good as the ones from the radical IL $[4,5,6]$.

An endoscopic procedure, with small incisions away from the dissecting area, seems to be a new and attractive approach duplicating the standard open procedure with less morbidity. In this paper, we present our initial clinical experience in retrograde Video Endoscopic Inguinal Lymphadenectomy (VEIL).

\section{CASE REPORT}

This is the first case of a prospective and comparative study between conventional procedure and VEIL in the same patient.

A 40 year old man with grade 3 squamous cell carcinoma of the penis without palpable nodes underwent a partial penectomy. Pathology revealed pT2NxMo with corpus cavernosum invasion. After patient's agreement, open left inguinal lymphadenectomy and right endoscopic inguinal lymphadenectomy were performed.

\section{Conventional radical technique}

The open procedure was done in the left side following the standard technique, removing both superficial and deep inguinal nodes (2).

\section{VEIL technique}

\section{Patient positioning and trocar placement.}

The patient is placed in supine position with thigh abduction. A $1.5 \mathrm{~cm}$ incision was made $2 \mathrm{~cm}$ distally of the lower vertex of the femoral triangle. Scissors were employed to develop a plane of dissection deep to Scarpa's fascia. The second incision was made $2 \mathrm{~cm}$ proximally and $6 \mathrm{~cm}$ medially. Two $10 \mathrm{~mm}$ Hasson trocars were inserted in these incisions and the working space was insufflated with $\mathrm{CO}_{2}$ at $5-15 \mathrm{mmHg}$. The last trocar was placed $2 \mathrm{~cm}$ proximally and $6 \mathrm{~cm}$ laterally from the first port (Figure 1).

\section{Dissection.}

Radical endoscopic right inguinal lymphadenectomy with the same template of open surgery was performed.The main landmarks - adductor longus muscle medially, the sartorius muscle laterally and the inguinal ligament superiorly -were well visualized. The retrograde dissection using the harmonic scalpel was started distally near the vertex of the femoral triangle towards the fossa ovalis, where safena vein was identified, clipped, and divided, and towards the femoral 
artery laterally. After the procedure, one can identify the skeletonized femoral vessels and the empty femoral channel, showing that the lymphatic tissue in this region was completely ressected. (Figure 2).

\section{Specimen retrieval and closure of ports.}

The surgical specimen was removed through the first port incision. A suction drain was placed to prevent lymphocele, and were kept until the drainage reached $50 \mathrm{~mL}$ or less in $24 \mathrm{~h}$.

\section{RESULTS}

Operative time was $130 \mathrm{~min}$ for the VEIL and 90 min for open surgery. On the right side (VEIL), the mean drain output was $80 \mathrm{~mL}$ and it was kept for 5 days. On the left, the mean output was 120 $\mathrm{mL}$ and the drain was kept for 6 days. There were no intra-operative complications. On the left side, a small area of skin necrosis occurred and was managed conservatively by debridement and ceftriaxon administration, without the need for a skin graft or flap. On the right side, there were no postoperative complications. Hospital stay was 10 days due to antibiotic therapy. The patient was asked to choose the technique he thought to be less morbid, and he chose the VEIL technique.

Pathology showed 7 negative nodes on the open side and 8 nodes on the endoscopic side, none of which were positive at pathology analysis. After 25 months follow-up, no sign of progression of the disease was observed.

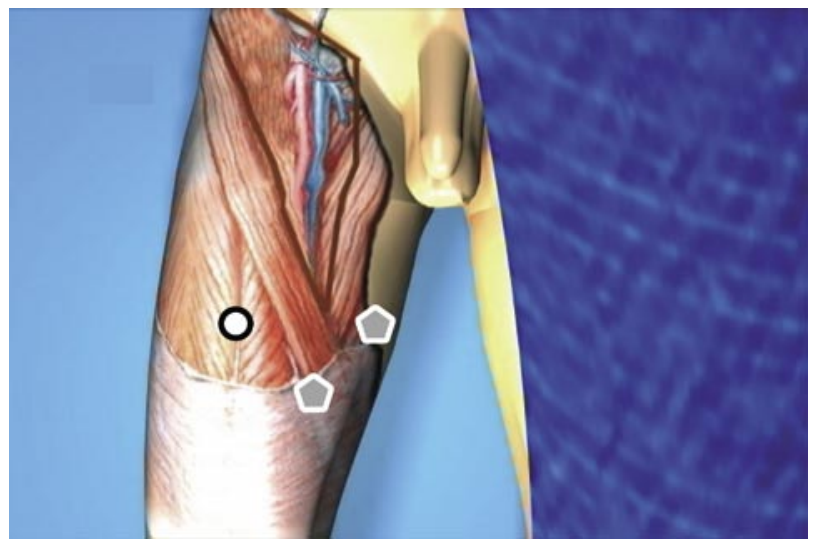

FIGURE 1. Trocars placement- $\square-10 \mathrm{~mm}$ trocar $5 \mathrm{~mm}$ trocar.

\section{DISCUSSION}

The VEIL technique was based on principles of endoscopic surgery of safena [7], aesthetic subcutaneous procedures [8] and endoscopic axillary node dissection [9].

Bishoff et al show the feasibility of subcutaneous modified endoscopic inguinal lymphadenectomy in cadaver [10]. They reported that dissection of a fixed node was difficult in one patient with inguinal palpable disease. With some technical modifications, we present the first experience comparing on the same patient the open and the endoscopic approach.

VEIL is feasible in the clinical practice. It is possible to identify the same landmarks of the open surgery and perform a dissection following the same template of the radical IL. We can see clearly through the endoscopic view if all lymphatic tissue within the limits of dissection has been removed at the end of the procedure.

New studies with a greater number of patients and long-term follow-up are needed to test the hypothesis that VEIL can keep the oncological efficacy of the standard surgery and may carry a lower morbidity.

If this hold true, VEIL can become an attractive choice for the prophylatic IL in penile cancer patients. Other possible clinical indications for this new procedure may include prophylatic dissection for urethral and vulvar cancers.

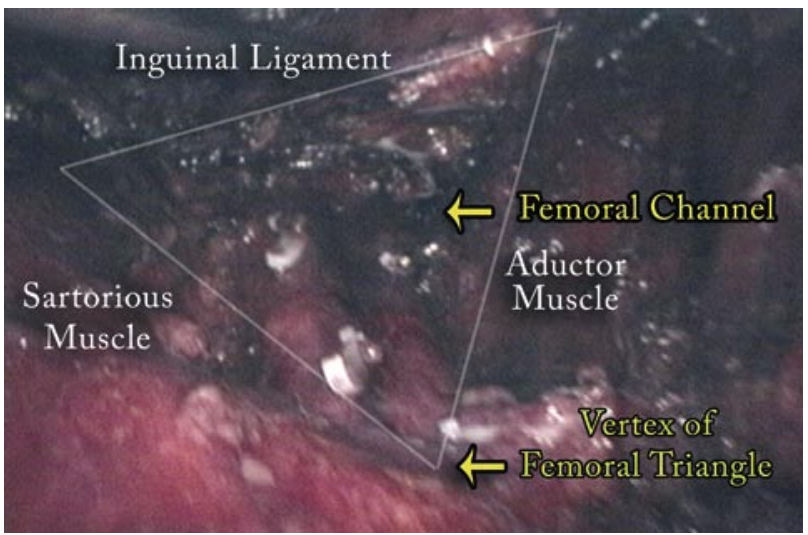

FIGURE 2. Endoscopic view of anatomic landmarks after radical ressection of inguinal lymphatic tissue through the VEIL technique 


\section{REFERENCES AND RECOMENDED READING \\ ( ${ }^{*}$ of special interest, ${ }^{* *}$ of outstanding interest)}

1. SRINIVAS, V.; MORSE, M.J.; HERR, H.W. y cols.: "Penile cancer: Relation of extent of nodal metastasis to survival". J. Urol., 137: 880, 1987.

2. ORNELLAS, A.A.; SEIXAS, A.L.C.; MAROTA, A. y cols.: "Surgical treatment of invasive squamous cell carcinoma of the penis: Retrospective analysis of 350 cases”. J. Urol., 151: 1244, 1994.

3. BEVAN-THOMAS, R.; SLATON, J.W.; PETTAWAY, C.A.: "Contemporary morbidity from lymphadenectomy for penile squamous cell carcinoma: the M.D. Anderson Cancer Center experience". J. Urol., 167: 1638, 2002.

*4. D'ANCONA, C.A.; DE LUCENA, R.G.; QUERNE, F.A. y cols.: "Long-term followup of penile carcinoma treated with penectomy and bilateral modified inguinal lymphadenectomy". J. Urol., 172: 498, 2004.

5. KROON, B.K.; HORENBLAS, S.; NIEWEG, O.E.: "Contemporary management of penile squamous cell carcinoma". J. Surg. Oncol., 89: 43, 2005.

*6. LOPES, A.; ROSSI, B.M.; FONSECA, F.P. y cols.: "Unreliability of modified inguinal lymphadenectomy for clinical staging of penile carcinoma". Cancer, 77 : 2099, 1996.

7. FOLLIGUET, T.A.; LE BRET, E.; MONETA, A. y cols.: "Endoscopic saphenous vein harvesting versus 'open' technique. A prospective study". Eur. J. Cardiothorac. Surg., 13: 662, 1998.

8. DARDOUR, J.C.; KTORZA, T.: "Endoscopic deep periorbital lifting: study and results based on 50 consecutive cases". Aesthetic Plast. Surg., 24: 292, 2000.

9. AVRAHAMI, R.; NUDELMAN, I.; WATENBERG, S. y cols.: "Minimally invasive surgery for axillary dissection". Cadaveric feasibility study: Surg Endosc., 12: 466, 1998.

*10. BISHOFF, J.A.; LACKLAND, A.F.B.; BASLER, J.W. y cols.: "Endoscopy subcutaneous modified inguinal lymph node dissection (ESMIL) for Squamous cell carcinoma of the penis". J. Urol., 169: 78, 2003. 